\author{
Michą SzcZyszeK \\ Uniwersytet im. Adama Mickiewicza \\ Instytut Filologii Polskiej
}

\title{
Przejawy internacjonalizacji we współczesnej polszczyźnie na przykładzie zjawisk słowotwórczych
}

Słow a klucze: internacjonalizacja, polszczyzna mówiona, system słowotwórczy, derywacja w polszczyźnie mówionej

Punktem wyjścia do niniejszego artykułu są rozważania dwóch badaczek polskiego słowotwórstwa: Krystyny Waszakowej oraz Hanny Jadackiej. Zwłaszcza praca tej pierwszej pt. Przejawy internacjonalizacji w stowotwórstwie wspótczesnej polszczyzny (Waszakowa 2005) skłoniła mnie do skupienia się na zakreślonym w temacie artykułu zagadnieniu; publikację Hanny Jadackiej System słowotwórczy polszczyzny (1945-2000) (Jadacka 2001) - traktuję natomiast jako swoiste uzupełnienie pracy K. Waszakowej (oraz interesującej mnie tu problematyki).

Książka K. Waszakowej dotyka ważkiego dla współczesnego języka polskiego problemu dużego nasycenia języka polskiego zapożyczeniami (zwłaszcza, w ostatnim czasie, angielskimi) czy strukturami językowymi o charakterze internacjonalnym. Autorka stawia tezę, iż proces globalizacji, tak szczegółowo opisywany na płaszczyźnie społecznej/socjologicznej, politycznej/politologicznej, ekonomicznej, na poziomie językowym przejawia się właśnie nasyceniem wszystkich dziś żywych języków naturalnych zapożyczeniami ze współczesnej lingua franca - angielszczyzny, zwłaszcza 
w jej wariancie amerykańskim. Swoje spostrzeżenia badaczka opiera głównie - co poświadcza zresztą tytuł książki - na materiale językowym współczesnej polszczyzny, zaczerpniętym przede wszystkim z dobrze znanej serii opracowań leksykograficznych: Nowe słownictwo polskie, a uzupełnionym źródłami dodatkowymi (Waszakowa 2005: 37-38). K. Waszakowa nie stroni jednak od przedstawienia faktów czy obserwacji lingwistycznych z terenu słowiańszczyzny. W rezultacie, z przytoczonych przez nią danych, poszerzonych gruntowną analizą zebranego materiału, wynika niezbicie, że zjawisko internacjonalizacji dostrzegalne jest we wszystkich współczesnych językach słowiańskich, w tym i w polszczyźnie.

Spostrzeżenia autorki odnośnie do nasycenia polszczyzny strukturami słowotwórczymi o charakterze internacjonalnym potwierdza choćby pobieżna kwerenda internetowa, wykorzystująca najpopularniejsze wyszukiwarki. Takiemu zabiegowi poddałem losowo wybrane z publikacji K. Waszakowej cząstki słowotwórcze - prefiksy o internacjonalnej proweniencji. Są to: anty-, arcy-, super-, post-. Przeprowadzone przeze mnie badanie internetowe miało bardzo prosty przebieg: kilka losowo wybranych leksemów z Indeksu neologizmów z książki K. Waszakowej (2005: 228-255) wpisałem do wyszukiwarki internetowej, po czym uzyskałem wynik w postaci liczby kontekstów, w których dany leksem się pojawił, oraz linków do samych kontekstów. Statystyczne wyniki tej kwerendy przedstawiają się następująco':

Derywaty z przedrostkiem anty-:

40500 kontekstów dla zapytania antykościót;

31800 kontekstów dla zapytania anty-rydzyk

25700 kontekstów dla zapytania antyprzykład

23900 kontekstów dla zapytania antyplagiat

18800 kontekstów dla zapytania antykultura

14200 kontekstów dla zapytania antypodatek

1230 kontekstów dla zapytania antymodel

694 konteksty dla zapytania antymotywacja

${ }^{1}$ Oczywiście, dane te - ze względu na naturę, właściwości Internetu (np. możliwość dotarcia do określonej informacji na kilka sposobów, kilkoma drogami, „łączami”) - należy traktować jedynie orientacyjnie (i tak są przeze mnie traktowane). 
Derywaty z przedrostkiem arcy-:

23800 - dla zapytania arcyparadoks

3250 - dla zapytania arcykatolik

899 - dla zapytania arcygeniusz

181 - dla zapytania arcymanipulator

97 - dla zapytania arcytragedia

65 - dla zapytania arcypomyst

65 - dla zapytania arcyrzemiosto

38 - dla zapytania arcydupek

Derywaty z przedrostkiem super-:

15400000 - dla zapytania superoferta

5450000 - dla zapytania supermen

139000 - dla zapytania superujęcie

107000 - dla zapytania superpomyst

76100 - dla zapytania superbomba

73200 - dla zapytania supernotebook

24900 - dla zapytania supermetoda

6380 - dla zapytania superstużby

Derywaty z przedrostkiem post-:

11100000 - dla zapytania postpunk ${ }^{2}$

55100 - dla zapytania postprodukcja

14000 - dla zapytania postfaszyzm

4210 - dla zapytania posthumanizm

3270 - dla zapytania postsolidarnościowiec

1180 - dla zapytania postsocjalizm

542 - dla zapytania postawangarda

220 - dla zapytania postsolidaruch

${ }^{2}$ W wypadku leksemu postpunk trudno zawyrokować, czy jest to zapożyczenie leksykalne (liczba kontekstów wskazywałaby, że tak, tzn. wyszukiwarka odnalazła wszystkie konteksty z użyciem tego wyrazu, jakie się pojawiły w globalnej sieci internetowej, a nie tylko na stronach polskojęzycznych), czy derywat utworzony na gruncie języka polskiego; K. Waszakowa (2005: 248) włącza tę strukturę do derywatów polskich (hybrydalnych), chociaż jej uzasadnienie może budzić wątpliwości. 
Przedstawione dane oczywiście nie dokumentują bezpośrednio wysokiej produktywności poszczególnych formantów słowotwórczych, a jedynie dużą i bardzo dużą (co doskonale widać w powyższym zestawieniu) częstość występowania derywatów (leksemów) w tekstach zamieszczonych na stronach nowoczesnego medium, bardzo ekspansywnego środka przekazu informacji - Internetu. Niemniej dane dotyczące częstości użycia derywatu (leksemu) z określonym formantem wskazują pośrednio również na określoną (dużą bądź nie) produktywność danego formantu. Tu faktycznie można obserwować, że te losowo wybrane formanty charakteryzują się wysoką produktywnością (por. rozważania o wpływie częstości użycia derywatów i formantów na produktywność formantów i jej oszacowywanie w: Satkiewicz 1969). Wydaje się wręcz, że tworzą one klasy otwarte derywatów (por. rozważania o problemie klas otwartych i słowotwórstwa potencjalnego w: Jadacka 2001: 142-143).

Uzyskane przeze mnie w toku pobieżnej kwerendy wyniki nie są sprzeczne z obserwacjami K. Waszakowej, która dowodzi, że polski system słowotwórczy ulega przeobrażeniom: z sufiksalnego (a więc typowo słowiańskiego) na system z większym udziałem prefiksów, prefiksoidów czy złożeń - typowego raczej dla języków germańskich, w tym dla angielszczyzny, dzisiaj dostarczającej największej liczby internacjonalizmów.

Podobny obraz przekształceń polskiego systemu słowotwórczego ostatniego półwiecza daje druga z przywołanych pozycji (nieco tylko wcześniej opublikowana niż książka K. Waszakowej) autorstwa H. Jadackiej. Badaczka ta, opierając się na tym samym źródle materiałowym, co K. Waszakowa, udokumentowała zmiany zachodzące w systemie słowotwórczym, polegające właśnie na powolnym, acz nieustannym procesie odchodzenia w polskim słowotwórstwie od sufiksacji na korzyść innych technik słowotwórczych: prefiksacji, paradygmatyzacji, kompozycji. Jadacka jednakże nadal dostrzega dominującą rolę słowotwórstwa morfologicznego, zwłaszcza sufiksacji tak typowej dla języków słowiańskich, w tym dla polskiego (Jadacka 2001: 143).

(Nie mogę w tym miejscu nie wspomnieć o wątpliwościach, jakie nasunęły mi się po lekturze książki H. Jadackiej odnośnie do produktywności poszczególnych wykładników słowotwórczych przez nią opisanych, a zatem pośrednio - o kształcie współczesnego polskiego systemu słowotwórczego i jego tendencjach ewolucyjnych. Swoją wątpliwość wyraziłem eksplicytnie w recenzji książki tej badaczki (Szczyszek 2002). Ponadto opracowałem mo- 
nografię jednego przyrostka funkcjonującego dziś (do dziś) w języku polskim (i w większości języków słowiańskich) (Szczyszek 2006). Obraz, wynikający z mojej monografii, nie w pełni pokrywa się z obserwacjami H. Jadackiej, a także K. Waszakowej.)

W tak zarysowanym - jak powyżej - kontekście teoretycznym, metodologicznym, materiałowym warto i wręcz należy postawić pytanie o to, czy procesy internacjonalizacji obejmują cały język polski (jakikolwiek język naturalny współcześnie używany), czy tylko niektóre jego warstwy, poziomy, odmiany? Na potrzeby niniejszego artykułu, przy tak zakreślonym w temacie jego zakresie, przedstawię wyniki analiz nad słowotwórczym materiałem polskim zebranym w ramach projektów realizowanych w UAM przez zespół badawczy DiaGest (o których to projektach i o którym to zespole - poniżej).

Zespół DiaGest, związany z Interdyscyplinarnym Centrum Przetwarzania Mowy i Języka UAM (Center for Speech and Language Processing AMU), prowadzi badania, których celem jest przeanalizowanie synchronizacji i korelacji zachodzących między mową (składnikiem werbalnym komunikacji interpersonalnej) a gestem (i pozostałymi składnikami niewerbalnymi (pozawerbalnymi) występującymi w komunikacji interpersonalnej). Dotychczas zespół przeprowadził dwa cykle badań. Polegały one na nagrywaniu na nośniki audio oraz wideo (kamery) zachowań komunikacyjnych uczestników nagrań, mających wykonać określone zadanie, a następnie otagowaniu zebranego materiału pod kątem zachowań gestologicznych, prozodii i rytmu wypowiedzi, składni, morfologii i leksyki (więcej na temat prac zespołu czytelnik znajdzie w artykułach, np.: Jarmołowicz, Karpiński, Malisz, Szczyszek 2007; Karpiński, Jarmołowicz-Nowikow, Juszczyk, Malisz, Szczyszek 2008).

Na potrzeby pierwszego cyklu nagrań „origami” zostało zaprojektowane zadanie wymagające od pary uczestników współpracy bazującej na rozmowie. Celem eksperymentu było wywołanie potrzeby przekazywania komunikatów zarówno za pomocą mowy, jak i gestów (czy szerzej: elementów pozawerbalnych) przynajmniej jednego z uczestników. Ustawione naprzeciw siebie osoby miały przydzielone - na czas trwania zadania - określone role: instruktora lub wykonawcy. Instruktor stał przed osłoniętym stołem, na którym położono arkusz papieru odpowiednio poskładany: origami, którego wykonawca nie widział. Zadanie instruktora polegało na przekazaniu wykonawcy informacji na temat tego, co widział na stole, natomiast zadaniem wykonawcy było zrekonstruowanie, na podstawie informacji instruktora, owego 
origami. Istotne było, że instruktor i wykonawca widzieli się wzajemnie oraz że stół wykonawcy i wszystko, co się na nim znajdowało, było widoczne dla instruktora, który w ten sposób miał możliwość korygowania swoich komunikatów. Przekaz informacji mógł się odbywać za pomocą różnych modalności: werbalnie i niewerbalnie. Uczestników eksperymentu nagrywaliśmy w przygotowanym akustycznie (wytłumionym) pomieszczeniu.

Na potrzeby drugiego cyklu nagrań „,children and adults” wyzyskaliśmy innego rodzaju eksperyment. Tym razem zadanie polegało na opowiedzeniu przez uczestników nagrań obejrzanego wcześniej filmu animowanego z cyklu „Kot Sylwester i kanarek Tweety”. Procedura przeprowadzenia nagrań została w dużej mierze oparta na procedurze stosowanej w podobnych badaniach, prowadzonych od wielu lat w McNeill Laboratory, tzn. uczestnicy nagrań po obejrzeniu - w izolacji - filmiku zapraszani byli do studia nagrań, sadzani na niekrępującym ruchów krześle ustawionym naprzeciw kamery; obok siadał moderator (członek zespołu z listą wszystkich epizodów filmu); zadaniem uczestnika nagrania było opowiedzenie całego filmu - moderator kontrolował, czy wszystkie epizody zostały w narracji przywołane, jeśli nie, to moderator dopytywał uczestnika nagrań o pominięte fragmenty. $\mathrm{Na}$ podstawie anotacji dziesięciu sesji z udziałem dziewięcioletnich dzieci oraz dziesięciu sesji z udziałem dorosłych (w przedziale wiekowym 20-40 lat) zespół zamierza m.in. zrealizować porównawcze badania nad wkładem gestu i mowy w wypowiedzi multimodalne, skupiając się na realizacjach wybranych aktów dialogowych. Projekt ten był realizowany jako część inicjatywy Multilingual and Multicultural Database of Cartoon Narration Recordings,

${ }^{3}$ Na potrzeby nagrań wykorzystaliśmy jeden 5-minutowy odcinek tej bajki, prezentowany w wersji angielskojęzycznej (przy czym komunikatów językowych nie jest w tym odcinku zbyt dużo). Kot Sylwester nieustannie próbuje złapać kanarka Tweety’ego, w czym zawsze Sylwestrowi przeszkadza właścicielka kanarka - babcia. Wykorzystany filmik składa się z kilku epizodów, np.: 1) kot próbuje się dostać po rynnie do okna, na którym stoi klatka z kanarkiem - kanarek zrzuca na kota kulę bilardową; 2) kot przebiera się za boya hotelowego i pomaga właścicielce kanarka wyprowadzić się z hotelu, w którym babcia z kanarkiem się zatrzymali - kot wyrzuca wszystkie bagaże, zatrzymując jedynie zasłoniętą klatkę, z której wyskakuje babcia i bije kota; 3) kot próbuje się katapultować do okna, na którym stoi kanarek, wykorzystując do tego dźwignię: kładąc deskę na kamieniu, staje na jednym jej końcu, a na drugi rzuca przygotowany zawczasu kilkutonowy ciężar - kotu udaje się porwać kanarka, ale spadając na dźwignię, powoduje wyrzucenie do góry tego wielkiego ciężaru z drugiego końca deski, który spada na głowę kota; itd. 
prowadzonej przez Annę Esposito (2nd University of Naples) w ramach Akcji COST 2012 (Cross-Modal Analysis of Verbal and Non-verbal Communication; na potrzeby udziału w tej Akcji zespół zrealizował grant badawczy: Komplementarność niewerbalnych $i$ werbalnych skladników wypowiedzi: Analiza porównawcza narracji dzieci i dorostych). Dzięki standardowym procedurom rejestracji korpusu, ujednoliceniu formatu oraz zadeklarowaniu sposobu opisu danych, możliwa jest wymiana wyników z innymi zespołami, a w konsekwencji - porównawcze badania interkulturowe.

Na uwagę zasługuje fakt, że po przeprowadzeniu obu cykli nagrań zespół DiaGest zgromadził bardzo bogaty korpus multimodalny (jedyny taki w Polsce). Jego niebagatelnym składnikiem jest zbiór nagrań żywej mowy, polskiego języka mówionego (mamy jednakże świadomość tego, że języka mówionego w sytuacji eksperymentu).

Na podstawie nagranego zbioru polszczyzny mówionej - na materiale werbalnym, językowym, po otagowaniu go z wykorzystaniem wskaźników morfosyntaktycznych (odwołujemy się tu do propozycji w: Woliński 2003 oraz Woliński, Przepiórkowski 2001) prowadzone są analizy syntaktyczne oraz morfologiczne, zwłaszcza w zakresie słowotwórstwa. Rezultaty tych ostatnich, przeprowadzonych na podstawie nagrań z pierwszego cyklu „origami”, zostały opublikowane w artykule: Konstrukcje słowotwórcze w dialogu zadaniowo-instruktażowym (Szczyszek 2009). Z kolei analizy wyników drugiego cyklu nagrań „children and adults” są w fazie wstępnej.

Na potrzeby niniejszego artykułu wyekscerpowałem z zebranego (nagranego) korpusu języka mówionego konstrukcje słowotwórcze, których struktura formalna wskazuje na obce, niepolskie pochodzenie, tzn. gdy albo temat słowotwórczy był obcego pochodzenia, albo gdy formant słowotwórczy był nierodzimy, albo też gdy cała struktura była obcego pochodzenia, jednak na gruncie polskim nabrała cech derywatu synchronicznego (por. Grzegorczykowa 1984: 14-16).

Co pokazał materiał językowy? Zwłaszcza w kontekście postawionego już wyżej pytania: czy procesy internacjonalizacji obejmują cały język polski, czy tylko niektóre jego warstwy, poziomy, odmiany?

Okazało się, że w materiale pochodzącym z pierwszego cyklu nagrań „origami” pojawiły się tylko dwa derywaty, które można uznać za powstałe pod obcym wpływem: panoramicznie, percepcja. W wypadku derywatu panoramicznie mamy do czynienia z nierodzimym tematem słowotwórczym; 
natomiast w wypadku konstrukcji percepcja należy stwierdzi, że jest to faktyczny internacjonalizm ${ }^{4}$, który na gruncie polszczyzny, wtórnie, zyskał status derywatu synchronicznego.

Materiał językowy zebrany podczas drugiego cyklu nagrań „children and adults" należy podzielić na dwie części: materiał dziecięcy i materiał dorosłych. W materiale dziecięcym nie odnalazłem ani jednej konstrukcji słowotwórczej o charakterze zapożyczonym, internacjonalnym czy hybrydalnym. Dziewięcioletnie dzieci, jeśli tworzyły derywaty bądź korzystały ze znanych im wyrazów podzielnych, to wyzyskiwały jedynie elementy rodzime.

Natomiast w materiale dorosłych pojawiło się 14 konstrukcji słowotwórczych, ale tylko o charakterze hybrydalnym: amerykański, bilardowy, filmik, ornitologiczny, sadystyczny, telefoniczny, teoretyczny, tradycyjny, tramwajowy, standardowo, przetransportować, momencik, elektryczny, fizyczny. Są to leksemy od dawna znane polszczyźnie i dobrze w niej zadomowione (co pokazała analiza leksykograficzna tych leksemów: skonfrontowałem je z ogólnymi słownikami polszczyzny: SJPDor., SJPSzym., ISJP, USJP, WSJP). Całość materiału słowotwórczego wyekscerpowanego z obu cykli nagrań liczy łącznie 309 wyrazów podzielnych słowotwórczo. Zatem, dodając 2 derywaty z nagrań „origami” do 14 derywatów z nagrań drugiego cyklu, uzyskamy procentowy stosunek struktur zapożyczonych (ogólnie mówiąc) do całości materiału słowotwórczego; wynosi on 4,5\% - taki odsetek całości materiału stanowią te właśnie zapożyczenia.

W trakcie analizy przeprowadzonej nad występującymi w zebranym materiale technikami słowotwórczymi, okazało się ponadto, że zarówno w nagraniach „origami”, jak i w ,children and adults” nie ma - z jednym wyjątkiem - formantów obcego pochodzenia (wspomniany wyjątek to przyrostek -cja w omówionym powyżej derywacie percepcja). Okazało się także, co jest niezmiernie ważne dla całościowego obrazu współczesnego polskiego systemu słowotwórczego i jego tendencji rozwojowych, że w zebranym materiale dominuje derywacja morfologiczna, zwłaszcza sufiksacja, rzadziej pojawia się paradygmatyzacja, a bardzo rzadko - złożenia, co pokazuje poniższe zestawienie:

${ }^{4}$ Por. ang. perception; franc. perception; hiszp. percepción. 
Drugi cyk1 nagrań „,children and adults”:

1) techniki słowotwórcze wyzyskane przez dzieci:

a) formanty rzeczownikowe: -ek, -ka, -ko, -nia, -anie, -cia, -cie, po-, formant paradygmatyczny, derywacja wsteczna;

b) formanty przymiotnikowe: $-s z y$;

c) formanty przysłówkowe: -'e, $-o,-e j$;

d) formanty czasownikowe: z-, po-, wy-, prze-, w-, za-, s-, przy-,ze-, przy-, $z e-$, we-, do-, ob-, od-, pod-, formant paradygmatyczny;

2) techniki słowotwórcze wyzyskane przez dorosłych:

a) formanty rzeczownikowe: od-, -ka, -enie, -ek, -cie, -anie, -ik, -nik, -stwo, -ynek, -ówka, -yni, -ość, -anko, -atko, -cia, -ar, -arz, -ica, -nia, -eczka, formant paradygmatyczny, -o- (złożenie);

b) formanty przymiotnikowe: naj-, nie-, -owy, -ny, -ty, -yczny, -iczny, -ej$s z y,-a n ́ s k i,-s z y,-u t k i,-e l n y,-o-$ (złożenie);

c) formanty przysłówkowe: - $e,-e j,-o$;

d) formanty czasownikowe: $w y-, s-, z-, p o-, p r z e-, p r z y-, w-, o d-$, we-, pod-, formant paradygmatyczny.

Stwierdzany zatem w przywoływanych książkach K. Waszakowej i H. Jadackiej proces przekształcania się polskiego systemu słowotwórczego drugiej poł. XX wieku - proces motywowany wpływem języków germańskich, zwłaszcza angielskiego; proces przeobrażania polegający na odchodzeniu od sufiksacji, czy szerzej - na odchodzeniu od derywacji morfologicznej na rzecz innych technik (złożeń, paradygmatyzacji) - nie jest prawdopodobnie tak zaawansowany (co można wnosić na podstawie badanego przez zespół DiaGest języka mówionego), jak można by przypuszczać na podstawie analiz przeprowadzonych przez obie autorki na materiale pochodzącym głównie ze środków masowego przekazu. Pojawiające się w materiale zespołu DiaGest hybrydy słowotwórcze to efekt - najprawdopodobniej - adaptacji morfologicznej (tu: słowotwórczej) elementów (tu: tematów słowotwórczych) obcego pochodzenia.

5 Wyniki analiz pierwszego cyklu nagrań „origami” opublikowałem w przywołanym już powyżej artykule (Szczyszek 2009); podczas analiz słowotwórczych przeprowadzanych przed napisaniem artykułu nie stwierdziłem w materiale językowym występowania formantów obcego pochodzenia, z wyjątkiem przyrostka -cja. 


\section{Wnioski}

1) Powstaje zatem pytanie: czy można wskazać granicę przenikalności do polszczyzny internacjonalizmów (zapożyczeń) słowotwórczych (z poziomu systemu słowotwórczego)? Czy można wskazać taką barierę przenikalności? Wydaje się, że tak. Tą barierą jest granica między językiem pisanym (pisanym wariantem polszczyzny) a językiem mówionym (mówionym wariantem polszczyzny). Język (wariant) pisany pozwala bowiem na większą refleksję autora wypowiedzi, daje możliwość zastanowienia się nadawcy nad formą podawczą, zwłaszcza w odmianach artystycznej i publicystycznej, na które powoływały się - zbierając materiał słowotwórczy do swoich analiz (głównie z tekstów publicystycznych) - K. Waszakowa i K. Jadacka. Język mówiony nie daje takich możliwości - w efekcie czego pojawiają się różnego rodzaju błędy i przejęzyczenia (niejednokrotnie opisywane w literaturze językoznawczej). Dlatego też - prawdopodobnie $-\mathrm{w}$ analizowanym przeze mnie materiale (pochodzącym z wariantu mówionego polszczyzny) nie pojawiały się w dużej liczbie nowe zapożyczenia i internacjonalizmy, a te, które się śladowo pojawiły, to jednostki leksykalne nieobce polszczyźnie (i jej użytkownikom) od dość dawna; mówiący bowiem wykorzystują raczej znane sobie leksemy, czy tu raczej: konstrukcje słowotwórcze i tradycyjne techniki słowotwórcze.

2) Sugestia socjolingwistyczna. Można przyjąć, że użytkownicy języka w codziennych, zwykłych, nieoficjalnych komunikatach raczej nie korzystają z elementów obcych (przynajmniej na poziomie faktów słowotwórczych), a tworzą komunikaty oparte na rodzimych środkach językowych (rodzimych derywatach, technikach słowotwórczych) - znamienny przypadek lektorki języka polskiego w Seulu ${ }^{6}$. Natomiast w sytuacjach oficjalnych strategia komunikacyjna się zmienia, co widać wyraźnie w środ-

${ }^{6}$ Znamienna jest tu przygoda polskiej lektorki języka polskiego pracującej w Seulu (zasłyszana od samej bohaterki). Lektorka - z wykształcenia koreanistka - chcąc skorzystać z pomocy sąsiedzkiej w bloku, w którym w Seulu wynajmowała mieszkanie, chciała swoją prośbę objaśnić sąsiadce Koreance, kobiecie w średnim wieku, po koreańsku; sąsiadka stwierdziła, że nie potrafi jej pomóc, jednakże zawołała swojego syna, który zaproponował rozmowę po angielsku. Zatem przez Koreankę rozmowa z przedstawicielką rasy białej, Europejką, była traktowana jako sytuacja oficjalna, w której jedynym narzędziem językowej komunikacji powinien być angielski (lingua franca, którego, notabene, Koreanka nie znała), a koreański - jako język „,regionalny” został zarezerwowany dla 
kach masowego przekazu: prasa, radio, telewizja, Internet. W językowej komunikacji pisanej, zwłaszcza tej dokonywanej przez media masowe, nieco inaczej przejawia się kompetencja komunikacyjna (na temat kompetencji komunikacyjnej por. Kurcz 2000: 16-17): tu jest czas na autorską refleksję nad komunikatem oraz - co chyba istotniejsze - tu jest miejsce na autokreację (również językową) nadawcy. Dlatego też w polskich tekstach prasowych pojawia się bardzo dużo zapożyczeń i internacjonalizmów - tu strategia komunikacyjna nakazuje bowiem nadawcom tworzenie komunikatów, nawet o błahych sprawach, w taki sposób, aby forma komunikatu zwracała na siebie uwagę odbiorców, np. poprzez stosowanie zapożyczeń czy internacjonalizmów. Odbiorcy dostają także dodatkową informację o nadawcy: autor komunikatu zna języki obce, zna zatem świat, kompetencja językowa (zwłaszcza odnośnie do znajomości nie tylko języka rodzimego) i kompetencja komunikacyjna autora takiego przekazu jest pokazana jako znacznie przewyższająca powszechną normę dla danego społeczeństwa. $\mathrm{Z}$ tych powodów nie powinno dziwić, że zarówno K. Waszakowa, jak i K. Jadacka, które analizy w swoich monografiach oparły głównie na języku współczesnych mediów polskich, stwierdziły, że proces internacjonalizacji polskiego systemu słowotwórczego jest obecnie bardzo zaawansowany. Tym samym nie powinien zastanawiać fakt, że wyniki przeprowadzonej przeze mnie kwerendy internetowej potwierdziły spostrzeżenia obu badaczek. Jednakże w wariancie mówionym polszczyzny sytuacja przedstawia się nieco inaczej, co - mam nadzieję - (przynajmniej w sposób przyczynkarski) wykazałem w tekście. Kontynuując polemikę z książką K. Waszakowej, należy przyznać słuszność jej stwierdzeniu, iż proces globalizacji przejawia się w języku tym, że wzrasta znacząco w polszczyźnie (i w językach słowiańskich) liczba anglicyzmów oraz internacjonalizmów o rodowodzie angielskim (Waszakowa 2005: 194-208). Z jednym jednak zastrzeżeniem. Rację ma badaczka w odniesieniu do komunikatów pisanych, zwłaszcza z odmiany publicystycznej języka polskiego czy komunikatów, które docierają do odbiorców poprzez globalną(!) sieć komputerową - Internet. Natomiast wydaje się, że w odniesieniu do wariantu mówionego polszczyzny moż-

kontaktów nieoficjalnych, czyli dla kontaktów z Koreańczykami (nie z przedstawicielami innych kultur). 
na zastosować analogiczne porównanie, tzn. komunikaty mówione, zarezerwowane dla sytuacji nieoficjalnych, będą podlegały przeciwnej do zjawiska globalizacji tendencji: tendencji do regionalizacji, objawiającej się na poziomie językowym właśnie wyzyskiwaniem głównie rodzimych (a jeśli obcych, to dobrze utrwalonych w języku) struktur językowych.

3) Drobna sugestia psycholingwistyczna. W obu cyklach nagrań przeprowadzonych przez zespół DiaGest brały udział dziewięcioletnie dzieci oraz dorośli powyżej 20 roku życia. Owe dzieci prawdopodobnie jeszcze nie opanowały w stopniu dostatecznym języka obcego (angielskiego); ba, znajdują się na ostatnim etapie nabywania języka pierwszego (Kurcz 2000: 73-74). Dorośli natomiast niekoniecznie musieli traktować udział w nagraniach jako sytuację oficjalną (co zresztą było celem zespołu badawczego: odoficjalnienie sytuacji komunikacyjnej zaistniałej podczas nagrań). Powstaje zatem pytanie: jak w tak skonstruowanej sytuacji komunikacyjnej zachowaliby się pod względem językowym nastolatkowie, którzy są właśnie w okresie ekspansji kompetencji językowych i komunikacyjnych; to pytanie pozostaje otwarte, dopóki nie zostaną przeprowadzone odpowiednie badania.

4) Z zaprezentowanych powyżej powodów warto zatem przemyśleć ponownie i przeformułować teoretyczne modele polskiego (współczesnego) systemu słowotwórczego w taki sposób, aby uwzględniały materiał z wariantu mówionego języka polskiego (o czym pisałem w przywołanym wyżej swoim tekście, por. Szczyszek 2009).

\section{Objaśnienia skrótów}

ISJP - Bańko M. (red.), 2000, Inny słownik języka polskiego, t. 1-2, Warszawa: Wydawnictwo Naukowe PWN.

SJPDor. - Doroszewski W. (red.), 1958-1969, Stownik języka polskiego, t. 1-11, Warszawa: Państwowe Wydawnictwo Wiedza Powszechna.

SJPSzym. - Szymczak M. (red.), 1999, Stownik języka polskiego, t. 1-3, wydanie I z włączonym suplementem, Warszawa: Wydawnictwo Naukowe PWN.

USJP - Dubisz S. (red.), 2003, Uniwersalny stownik jezzyka polskiego, t. 1-4, Warszawa: Wydawnictwo Naukowe PWN.

WSJP - Dunaj B. (red.), 2007, Stownik współczesnego języka polskiego, t. 1-2, Warszawa: Wydawnictwo Langenscheidt. 


\section{Bibliografia}

Grzegorczykowa R., 1984, Zarys stowotwórstwa polskiego. Stowotwórstwo opisowe, Warszawa: Państwowe Wydawnictwo Naukowe.

JADacka H., 2001, System stowotwórczy polszczyzny (1945-2000), Warszawa: Wydawnictwo Naukowe PWN.

JarmoŁowicz E., Karpiński M., Malisz Z., Szczyszek M., 2007, Gesture, Prosody and Lexicon in Task-Oriented Dialogues: Multimedia Corpus Recording and Labelling, Lecture Notes in Artificial Intelligence. Subseries of Lecture Notes in Computer Science, $\mathrm{nr}$ 4775, s. 99-110.

Karpiński M., JarmoŁowicz-Nowikow E., Malisz Z., Szczyszek M., Juszczyk K., 2008, Rejestracja, transkrypcja i tagowanie mowy oraz gestów w narracji dzieci i dorosłych, Investigationes Linguisticae, vol. 16, s. 1-14.

Kurcz I., 2000, Psychologia języka i komunikacji, Warszawa: Wydawnictwo Naukowe „Scholar”.

SAtKiewicz H., 1969, Kryterium ilościowe jako wskaźnik produktywności formantów słowotwórczych, Prace Filologiczne XIX, s. 109-118.

Szczyszek M., 2002,/rec./, Hanna Jadacka, System słowotwórczy polszczyzny (1945-2000), Język Polski LXXXII, s. 150-154.

Szczyszek M., 2006, Derywaty z przyrostkiem -owicz w języku polskim (doba nowopolska), Poznań: Wydawnictwo „Poznańskie Studia Polonistyczne”.

Szczyszek M., 2009, Konstrukcje stowotwórcze $w$ dialogu zadaniowo-instruktażowym, w: E. Graf, J. Rabiega-Wiśniewska, N. Thielman (red.), Beiträge der Europäischen Slavistischen Linguistik (Polyslav), Band 12, München: Verlag Otto Sagner, s. 167-176.

Waszakowa K., 2005, Przejawy internacjonalizacji w słowotwórstwie wspótczesnej polszczyzny, Warszawa: Wydawnictwo Uniwersytetu Warszawskiego.

WoliŃski M., 2003, System znaczników morfosyntaktycznych w korpusie IPI PAN, Polonica XXII-XXIII, s. 39-55.

Woliński M., PrZePIórkowski A., 2001, Projekt anotacji morfosyntaktycznej korpusu języka polskiego, Warszawa: Wydawnictwo IPI PAN. 


\section{Internationalisation processes in modern Polish: word-formation phenomena}

( s u m m a r y)

In this paper I present the results of the DiaGest Research Group studies on multimodal interpersonal communication (interpersonal verbal and nonverbal communication behaviours). For the purpose of this paper I have analysed word-formation structures which occur in the DiaGest Research Group database (this database collects spoken Polish utterances), in search for derivatives with foreign, non-Polish components (e.g. formative stems or suffixes). However, I found only a few derivatives with the foreign component: scarcely $4,5 \%$ of whole word-formation collection in the DiaGest's database. This result suggests that the internationalisation processes in modern Polish (in spoken Polish), particularly in the word-formation system, described by Waszakowa (2005), and also to some extent Jadacka (2001), are not as advanced as might appear from these two studies.

These facts point to the need of a fresh reconsideration of the theoretic model of modern Polish word-formation system, a model which would include spoken Polish. 